\title{
The Modern Class action Comes to Alberta
}

\author{
MARGARET A. SHONE, Q.C.

\section{Statutory EnaCtMent}

Alberta's Class Proceedings Act received Royal Assent on 16 May 2003 and was proclaimed in force 1 April 2004.' The Alberta Act adopts many of the recommendations made in the Alberta Law Reform Institute's (ALRI) Final Report No. 85 on Class Actions issued December 2000. In turn, ALRI's recommendations closely follow the provisions in the Class Proceedings Act adopted by the Uniform Law Conference of Canada (ULC) in $1996 .^{3}$ The $U L C$ Act serves as the prototype for modern class action regimes in Canada. In enacting a modem class action regime, Alberta joins seven other Canadian jurisdictions, six of which have introduced their provisions since 1990. Although modern class action legislation has its opponents, ${ }^{3}$ the positive legislative response attests to the more widely held view that this legislation embodies a welcome procedural improvement.

A class action enables persons having the same or similar claims against a defendant to pursue their claims through one party who "represents" the interests of all of the members of the class in the lawsuit. It is a procedural device. It does not arm a litigant with any additional substantive rights or remedies. The class members, although not parties to the proceeding, are bound by the outcome. By allowing several claims to be brought through one person, a class action may be said to enhance judicial economy, improve access to justice and deter wrongful conduct. ${ }^{6}$ The device is particularly useful in cases where each class member's claim is small but the aggregate claim is large enough to support litigation.

\section{Historical Perspective.}

To the public who learn of the recent legislative activity through the media, class actions may appear to be an idea whose time has come. However, grouping persons together for the purpose of litigation is not a recent innovation. The origin of class actions can be traced back

Counsel, Alberta Law Reform Institute, Edmonton, Alberta.

S.A. 2003, c. C.16.5 [Alberta CPA].

Alberta Law Reform Institute, Class Actions, Final Report No. 85 (Edmonton: ALRI, 2000).

Uniform Law Conference of Canada, Class Proceedings ACl, online: Uniform Law Conference of Canada - Uniform Statutes < $w w w$.ulcc.ca/en/us/index.c/m?sec=1\&sub=] c2> [ULC CPA].

In Ontario, Class Proceedings Act. 1992, S.O. 1992, c. 6 (effective I January 1993) [Ontario CPA]; in British Columbia, Class Proceedings Act, R.S.B.C. 1996, c. 650 (first enacted as S.B.C. 1995, c. 21, effective I August 1995); in Newfoundland and Labrador, Class Actions Acl, S.N.L. 2001, c. C-18.1 (enacted 13 December 2001, effective 1 April 2002); in Saskatchewan, Class Acrions Act, S.S. 2001 ,c. C-12.01 (effective I January 2002); in Manitoba, Class Proceedings Act, C.C.S.M., c. C-130 (assented to 25 JuJy 2002, effective I January 2003); in Federal (ourt Rules, SOR/98-106, rr. 299.1-299.42 as am. by SOR/2002-417. Quebec preceded these jurisdictions: see C.C.P.

For a list of objections and responses, see ALRI, supra note 2 at $46-49$.

See Ontario Law Reform Commission (OLRC). Report on Class Actions, vol. 1-3 (Toronto: Ministry of the Atlomey General, 1982) (these three objectives are identified); Western Canadian Shopping Centres v. Dutton, [2001] 2 S.C.R. 534 at paras. 27-29 [Western Canadian Shopping Centres] (the Supreme Court of Canada describes these objectives as three important advantages of class actions over a multiplicity of suits). 
to Chancery practice in England in the 17th and 18th centuries. In cases where numerous persons had an interest in the outcome of a dispute, the Courts of Equity allowed them to appear through a representative rather than be joined individually. When the Courts of Common Law and Courts of Equity merged in $1873,{ }^{7}$ the Chancery practice was incorporated in what is known as the representative action rule - Rule 42 in Alberta. ${ }^{8}$ Most jurisdictions in Canada and elsewhere in the Commonwealth still have representative action rules." These rules remain essentially the same as the rule adopted in England in $1873 .^{10}$

Whereas the Courts of Equity had taken a liberal and flexible approach to representative actions, after the merger the approach became more restrictive. The merged courts were particularly reluctant to permit representative actions in cases where common law remedies such as damages were being sought. In Canada, the courts continued to restrict the availability of representative actions until 2001 when the Supreme Court of Canada issued its landmark judgment in the case of Western Canadian Shopping Centres."

A mere 18 years earlier, in the 1983 case of General Motors of Canada Lid. $v$. Naken, ${ }^{12}$ the Supreme Court did not see a clear path to expanding the scope of the representative action rule. The courts could not take this initiative even though the concept of a modem class action was beginning to take hold in North America. A modern class action regime had been introduced in 1938 in the United States and substantially broadened through amendments in the early 1950s and again in $1966 .^{13}$ In 1979, Quebec had followed the American lead by enacting modern class action provisions in its Code of Civil Procedure ${ }^{14}$ and, in 1982, the Ontario Law Reform Commission had made recommendations for the adoption of a modern class action regime. ${ }^{\text {is }}$ This information was known when the Supreme Court of Canada rendered judgment in the Naken case, but it did not lead the Court to modify its position on the law. Instead, the Court identified "the need for a comprehensive legislative scheme for the institution and conduct of class actions."16

Supreme Court of Judicature Act, 1873 (U.K.), 36 \& 37 Vict., c. 66.

Alberta Rules of Court, $r .42$, which provides:

Where numerous persons have a common interest in the subject of an intended action, one or more of those persons may sue or be sued or may be authorized by the Court to defend on behalf of or for the benefit of all.

In some jurisdictions, a modem class action regime replaces the representative action rule. In others, the rule survives alongside the modern regime.

Rules of Procedure, r. 10, being Schedule to the Supreme Court of Judicature Act, 1873 (U.K.), 36 \& 37 Vict., c. 66 . Rule 10 provides:

Where there are numerous parties having the same interest in one action, one or more of such parties may sue or be sued, or may be authorised by the Court to defend in such actions, on behalf or for the benefit of all parties so interested.

Supra note 6 at para. 24.

General Molors of Canada Lid. v. Naken, [1983] I S.C.R. 72 [Naken].

Federal Rules of Civil Procedure for the United States District Courts, r. 23 (effective 16 September 1938 as am. by 28 February 1966, effective 1 July 1966; 7 March 1987, effective 1 August 1987; 24 April 1998, effective I December 1998).

C.C.P. (first enacted as S.Q. 1978, c. 8, s. 3, effective 19 January 1979).

OLRC, supra note 6.

Supra note 12 at 105. See also Western Canadian Shopping Centres v. Durton (1998), 228 A.R. 188 at 193 (C.A.), Russell J.A. ("This area of the law is clearly in want of legislative reform to provide a more uniform and efficient way to deal with class action lawsuits"), appeal dismissed and cross appeal allowed on appeal to S.C.C.; Western Conadian Shopping Centres, supra note 6. 
In 2001, in the Western Canadian Shopping Centres case, the Supreme Court of Canada made a surprise departure from previous jurisprudence. Eighteen years after Naken, the Court affirmed the power — indeed, the duty - of the courts to modernize the structure representative actions where this would be an appropriate means of managing issues. ${ }^{17}$ It was no longer necessary to wait for the Legislatures to enact legislation.

What had happened since 1983 to change the Court's mind about the need for the legislatures to act? One factor was the experience in Canada under recently enacted class action legislation. In 1992, almost a decade after the Supreme Court's judgment in the Naken case, Ontario had enacted its Class Proceedings $\mathrm{Act},{ }^{18}$ thereby leading a wave of class action activity in Canada's common law jurisdictions. British Columbia had followed by enacting its statute in $1995 .^{19}$ The ULC had adopted its uniform prototype in $1996^{20}$ and other jurisdictions were considering the need for legislation. ${ }^{21}$ The experience under the class action legislation that had been enacted in Quebec, Ontario and British Columbia had set a sufficient example for the Supreme Court. In exercising their power and carrying out their duty to structure class proceedings in jurisdictions that had not enacted class action legislation, courts were now to be guided by the procedures laid out in modern class action legislation in Quebec, Ontario and British Columbia.

A second factor may have been a judicial trend toward liberalization of the approach taken to the interpretation of representative action rules, the signs of which could be traced in cases following the Supreme Court of Canada's judgment in the Naken case. ${ }^{22}$

A third factor had to do with the global interconnectedness of today's world. In explaining its shift in position, the Supreme Court drew on emerging conditions that parallel "the problem that had motivated the development of the class action in the eighteenth century -

Supra note 6 at para. 34.

Supra note 4; see also Government of Ontario, Reporl of the Attorney General's Advisory Committee on Class Actions Reform (Toronto: The Committee, 1990).

Class Proceedings Act, supra note 4; see also British Columbia Ministry of the Attorney General. Consuliation Document: Class Action Legislation for British Coltumbia (Victoria: Queen's Printer. May 1994).

ULC CPA, supra nole 3.

Manitoba Law Reform Commission (MLRC). Class Proceedings, Report 100 (Winnipeg: MLRC, 1999); ALRI, supra nole 2; Federal Court of Canada Rules Committee, Class Proceedings in the Federal Court of Canada: Discussion Paper (Ottawa: Federal Court, Rules Committee, 2000). Prince Edward Island introduced a class action bill in 1997, but it died on the order paper.

See Douglas A. McGillivray \& Graham McLennan, "Shattering the Myth Behind Western Canadian Shopping Centres Inc. v. Dutton" in J.J. Camp \& Douglas A. McGillivray, eds., Litigasing Class Actions: the Roadmap for Bringing and Defending Class Actions in Western Canada (Toronto: The Canadian Institutc, 2002) at 4-8. In support of this trend McGillivray and McLennan cite: Ranjoy Sales \& Leasing Lid. v. Deloille, Haskins \& Sells (1984), 16 D.L.R. (4th) 218 (Man. C.A.), leave to appeal to S.C.C. refused (1985), 16 D.L.R. (4th) 218; Alberta Pork Producers Marketing Board v. Swiff Canadian Co. (1984), 53 A.R. 284 (C.A.), leave to appeal to S.C.C. refused (1984), 58 A.R. 1: Korte v. Deloitte, Haskins \& Sells (1993), 135 A.R. 389 (C.A.), leave to appeal to S.C.C. refused, [1993] 3 S.C.R. v; Anderson Exploration v. Pan-Alberla Gas Lid. (1998), 229 A.R. 191 (Q.B.), additional reasons in (1999), 242 A.R. 179 (Q.B.). Setbacks in the road to a liberal interpretation of the representative action rule were also incurred: see Ahktar v. MacGillivray \& Co. (1984), 55 A.R. 206 (Q.B.). 
the problem of many suitors with the same grievance."23 In "invok[ing] the utility of the class action," the Court stated:

The class action plays an important role in today's world. The rise of mass production, the diversification of corporate ownership, the advent of the mega-corporation, and the recognition of environmental wrongs have all contributed to its growth. A faulty product may be sold to numerous consumers. Corporate mismanagement may bring loss to a large number of shareholders. Discriminatory policies may affect entire categories of employees. Environmental pollution may have consequences for citizens all over the country. Conflicts like these pit a large group of complainants against the alleged urongdoer. Sometimes, the complainants are identically situated $v i s-d$-vis the defendants. In other cases, an important aspect of their claim is common to all complainants. The class action offers a means of efficiently resolving such disputes in a manner that is fair to all parties. ${ }^{24}$

\section{KEY FEATURES}

The representative action rule does not specify the procedure to be followed. Much depends on the court's exercise of its inherent jurisdiction to control the conduct of proceedings and on the court's broad power - in Alberta under s. 8 of the Judicature Act's - to handle a matter so as to avoid all multiplicity of proceedings. Prior to 2001, a maze of case law had made the practice under the representative action rule difficult to discover and largely unpredictable. Modern legislative regimes build on the historic representative action concept, but are "designed to be a flexible procedure that overcomes many of the perceived constraints and limitations of representative actions." ${ }^{26}$ They offer clearer procedures that improve the ability of counsel "to provide advice to their clients, whether they be plaintiffs or defendants, on the procedural aspects" of a class action. ${ }^{27}$

The Supreme Court of Canada judgment in the Western Canadian Shopping Centres case brings proceedings under the representative action rule into closer alignment with modern class action regimes. However, it does not go the full distance. For this reason, Canadian jurisdictions have continued to legislate modern regimes. Newfoundland and Labrador ${ }^{28}$ and Saskatchewan ${ }^{29}$ enacted statutes in 2001, Manitoba did so in 2002, ${ }^{30}$ and Alberta followed in 2003. ${ }^{31}$ The Federal Court of Canada gazetted new Rules in 2001.32

The decision in Western Canadian Shopping Centres broadens the scope of representative actions under the historic rule. Nevertheless, legislated class action regimes continue to offer greater procedural certainty. The greater certainty and related advantages of modern class actions can be demonstrated by examining selected features of the newly legislated regimes.

Western Canadian Shopping Centres, supra note 6 at para. 25.

Ibid. at para. 26.

Judicature Act, R.S.A. 2000, c. J-2.

James Sullivan, A Guide to the British Columbia Class Proceedings Act (Toronto: Butterworths, 1997) at $\mathrm{l}$.

McGillivray \& McLennan, supra note 22 at 10.

Supra note 4.

Ibid.

Ibid.

Alberta CPA, supra note 1.

Supra note 4. 
As shown in the paragraphs that follow, some of these features now apply to representative actions (for example, certification, the creation of subclasses, notice to persons in the defined class, and discovery). However, the applicability of other features of modern class actions to representative actions remains uncertain (for example, the court's role in protecting the interests of class members, aggregated damages, limitation periods, costs and appeals).

Because this is a comment on the Alberta Act, sections in the Alberta Class Proceedings $A c t$ are cited. Provisions in the modern legislation in other Canadian jurisdictions are generally similar. Two Canadian looseleaf binder services give up-to-date accounts of the case law on modern class actions: Ward K. Branch's Class Actions in Canada, ${ }^{33}$ and Michael A. Eizenga, Michael J. Peerless and Charles M. Wright's Class Actions Law and Practice. ${ }^{34}$

\section{A. Certification}

In a modern class action, the court must approve - that is, "certify" - a class proceeding before it can go forward. The certification process is designed to ensure that class action procedures are appropriate to handle the claims of the persons in the defined class. The following five criteria must be satisfied:

(a) the pleadings disclose a cause of action:

(b) there is an identifiable class of 2 or more persons;

(c) the claims of the prospective class members raise a common issue, whether or not the common issue predominates over issues affecling only individual prospective class members:

(d) a class proceeding would be the preferable procedure for the fair and efricient resolution of the common issues:

(c) there is a person eligible to be appointed as a representative plaintiff who, in the opinion of the Court (i) will fairly and adequately represent the interests of the class,

(ii) has produced a plan for the proceeding that sets out a workable method of advancing the proceeding on behalf of the class and of notifying class members of the proceeding, and

(iii) does not have, in respect of the common issues, an interest that is in conflict with the interests of other class members. ${ }^{35}$

In Western Canadian Shopping Centres, the Supreme Court imposed an analogous requirement for advance approval from the court to proceed under the representative action rule. Previously, a case brought under the representative action rule would proceed unless the defendant raised an objection.

\section{B. SUbClasses}

Subclasses, each with its own representative plaintiff, may be formed under class action legislation. ${ }^{36}$ The formation of subclasses is now possible under the representative action rule 
as well. Previously, subclasses were not allowed because class members had to share in common the principal issues of law and fact and claim the same remedy.

\section{Notice}

Modern class action provisions require notice of certification to be given to potential class members so that they will have an opportunity to decide whether or not they want to be part of the class and bound by the result. ${ }^{37}$ The court must approve the notice and manner in which it is to be conveyed. Notice is also given to class members where, following determination of the common issues, class member participation is required to determine individual issues. ${ }^{38}$ Western Canadian Shopping Centres endorses the requirement for notice of certification in representative actions. The Supreme Court of Canada has stated that

prudence suggests that all potential class members be informed of the existence of the suit, of the common issues that the suit seeks to resolve, and of the right of each class member to opt out, and that this be done before any decision is made that purports to prejudice or otherwise affect the interests of class members. ${ }^{39}$

The manner of dealing with individual issues after the common issues have been resolved is left to the exercise of the court's discretion on a case by case basis "in a flexible and liberal manner seeking a balance between efficiency and fairness." ${ }^{40}$ Previously, under the representative action rule, the requirements regarding notice to class members were less clear.

\section{JUdicial Role}

Modern class action legislation calls for active judicial case management in order to ensure that the action proceeds fairly and efficiently and that the interests of class members are adequately protected. The court role includes:

(a) certification of the proceeding as a class action; ${ }^{41}$

(b) approval of

(i) notices to class members (certification of the proceeding, opportunity to decide whether or not to be in the class, resolution of the common issues, whether by settlement or judicial disposition), ${ }^{42}$

(ii) the settlement, discontinuance, abandonment or consent dismissal of an action, ${ }^{43}$ and

(iii) any agreement between the representative plaintiff and class counsel for the payment of lawyer fees and disbursements; ${ }^{44}$

Ibid., s. 20.

Ibid., s. 21.

Supra note 6 at para. 49.

lbid. at para. 51 .

Alberta CPA, supra note 2, ss. 2-11.

Jbid., ss. 20, 21.

Ibid., ss. 4, 35 .

Ibid., ss. 38, 39 . 
(c) exercise of judicial discretion to allow class members to participate in the proceeding;, and

(d) making provision for the determination of individual issues separate from the common issues. $^{46}$

In Western Canadian Shopping Centres, the Supreme Court does not address the role of the court in approving settlements, discontinuances, abandonment or consent dismissals, or in approving agreements between the representative plaintiff and class counsel for the payment of fees and disbursements. American experience demonstrates the potential for abuse of class members where representative plaintiffs accept personal settlements in exchange for dismissal of the action as if it had been tried on the merits.

\section{E. Membership in Class}

Ordinarily, under class action legislation, persons who come within the definition of the class are members of the class unless they "opt out" of the proceeding. Some jurisdictions, including Alberta, require non-residents to "opt in" to the proceeding by taking a positive step. ${ }^{47}$ Other jurisdictions are silent about the territorial limits of class membership, opening up the potential for the certification of a "national" class. ${ }^{43}$

\section{F. Discovery}

One of the issues before the Supreme Court in Western Canadian Shopping Centres was the right to discover class members in a representative action. The Court held that the defendants should be allowed to examine the representative plaintiffs as of right but examination of other class members should be available only by order of the court, upon the defendants showing reasonable necessity. In the circumstances of this case, a decision about the examination of class members would be premature. The Court's holding is consistent with provisions in modern class action legislation. ${ }^{49}$

\section{G. MONETARY RELIEF}

Under class action legislation, damage awards arising from the resolution of the common issue may be assessed on an individual or aggregated basis (in which case provision is made for subsequent distribution to class members).$^{50}$ Provision is also made for the subsequent assessment of damages on individual issues." The Supreme Court of Canada did not address the assessment and distribution of damage awards under the representative action rule.

Ibid., s. 16.

Ibid., s. 28.

Ibid., s. 17. The ULC ACt employs this model, as do British Columbia, Saskatchewan and Newfoundland and Labrador.

Ontario and Manitoba provide examples of this model. The Ontario courts have allowed the creation of "national" classes: for cases, see Michael A. Eizenga, Michael J. Peerless \& Charles M. Wright, Class Actions Law and Practice, looseleaf (Toronto: Butterworths, June 1999). Alberta CPA, supra note I, s. 18. See also s. 19 on the examination of a class member as a witness before an application.

so Ibid., ss. 30-34.

s1 Ibid., s. 28. 


\section{H. Limitation Periods}

Class action legislation suspends the running of limitation periods against class members during the class proceeding, in this way protecting class members from the expiration of a limitation period. ${ }^{52}$ The representative action rule gives no such protection. To protect themselves, class members would have to take the precaution of comınencing their own action before the limitation period runs out. The Supreme Court of Canada is silent on this point.

\section{Costs}

The ordinary costs rules apply to representative actions, but uncertainty exists as to the liability of class members for costs if the action fails. Under class action legislation, the representative plaintiff is personally liable for costs, although the court may permit the representative plaintiff to solicit contributions from class members to assist in paying lawyers' fees and disbursements. ${ }^{53} \mathrm{Alberta}$ has chosen to apply the ordinary costs rule to class actions. ${ }^{54}$ Most Canadian jurisdictions have adopted a no-costs rule, meaning that each party (representative plaintiff and defendant) is responsible for their own costs. Quebec and Ontario have costs rules, but these provinces have provided a fund to assist the representative plaintiff in bringing the action. In Ontario, the class action legislation sets out factors the court may consider in assessing costs. The factors are that the class proceeding is a test case, raises a novel point of law or addresses an issue of significant public issue. ${ }^{55}$ These factors are not included in the Alberta Act. However, in the case of Pauliv. ACE INA Insurance, the Alberta Court of Appeal stipulated that judges exercising their broad discretionary powers over costs must adhere to criteria. The criteria support departure from the normal rule that costs follow the event when the issue constitutes a matter of broad public interest, raises a novel point of law, meets the requirements of a test case or access to justice would be seriously impaired. ${ }^{36}$ With reference to access to justice, the Court stated:

Class actions are relatively new in Canada, and it is arguable that such actions increase access to justice by allowing many claimants to pool their resources to pursue claims together that they could not pursue individually because of small monetary amounts at stake. But the reality is that large cost awards against unsuccessful plaintiffs will have a chilling effect and likely discourage meritorious class actions: Craig Jones, Theory of Class Actions, Irwin Law Inc., 2003 at p. 150. These arguments are reviewed in Final Report No. 85. Class .Actions, at pp. 147-154, Alberta Law Reform Institute, December, 2000. In exercising the court's discretion to award costs, there needs to be a balance between encouraging class actions that have potential merit and discouraging those that may be frivolous or vexatious. ${ }^{37}$

Ibid., s. 40.

lbid., s. 20(8).

lbid., s. 37.

Omario CPA, supra note 4, s. 31(1)

(2004), 242 D.L.R. (4th) 420 at paras. 21-34.

lbid. at para. 31. 


\section{J. APPEAL.}

Class action legislation specifies the circumstances in which a class member may bring an appeal to the Court of Appeal from the determination of the common issue. ${ }^{98}$ The Supreme Court of Canada did not address this matter in Western Canadian Shopping Centres.

\section{K. Defendant Class}

The representative action rule allows defendants to form a class. Similarly, modem class action legislation in some jurisdictions provides for the formation of a defendant class that is defended by a "representative defendant." 99 The Alberta $\mathrm{ACl}$ does not mention the possibility of a "defendant class." Therefore, proceedings involving a defendant class must be brought under r. 42 of the Alberta Rules of Court.

\section{FUTURE DiRECTION}

With the coming into force of the Class Proceedings $A c t$, Alberta class action law moves into the 21 st century. Alberta law now conforms with the class action model in force in a majority of Canadian jurisdictions, and much of the procedural uncertainty under the representative action rule is resolved. The legislature in Alberta has taken an important step toward achieving the three objectives of enhancing judicial economy, improving access to justice and deterring wrongful conduct in modern times. However, new challenges are emerging. Modern wrongs such as manufacturing defects, securities frauds or oil spills do not contain themselves within political borders. In pursuing the same three objectives, courts now wrestle with issues involving the definition of classes that are national or international in their embrace. They face questions about the circumstances in which it is appropriate for a court to take jurisdiction on a national or international basis, or to extend comity with respect to judgments rendered by courts in other jurisdictions. ${ }^{\circ}$

Alberta CPA, supra note 1, s. 36.

Ontario CPA, supra note 4, s. 4.

See e.g. Harrinton v. Dow Corning Corp. (2001), 193 D.L.R. (4th) 67 (B.C.C.A.); Nantais v. Telectronics Proprietary (Canada) Lid. (1995), 25 O.R. (3d) 331 (Gen. Div.); Carom v. Bre- ${ }^{\circ}$ Minerals Lid. (1999), 43 O.R. (3d) 44 I (Gen. Div.); Webb v. K-Marl Canada Lid. (1999), 45 O.R. (3d) 389 (Sup. Ct. J.); Wilson v. Servier Canada (2000), 50 O.R. (3d) 219 (Sup. Ct. J.); Wheadon v. Bayer Inc. (2004), 237 N丹ld. \& P.E.I.R. 179 (Nfld. S.C. (T.D.)). 